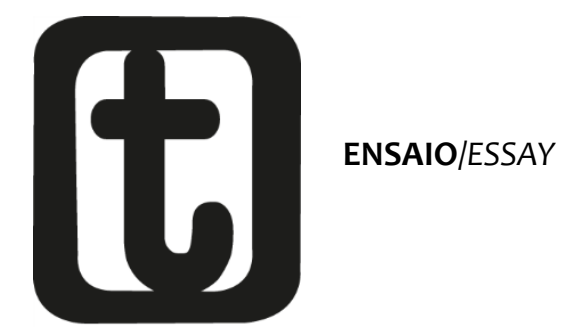

\title{
2011: PRIMAVERA ÁRABE?
}

2011: The Arab spring?

\section{Samir Amin}

O ano 2011 começou com uma série de explosões ressoantes de ira dos povos árabes. Esta primavera árabe começará um segundo tempo do despertar do mundo árabe ou essas revoltas vão patinar e finalmente abortar, como foi no caso do primeiro momento deste despertar evocado no meu livro O despertar do Sul? $\mathrm{Na}$ primeira hipótese, os progressos do mundo árabe inscrever-se-ão necessariamente no movimento de superação do capitalismo/imperialismo à escala mundial. $\mathrm{O}$ fracasso manteria o mundo árabe no seu estatuto atual de periferia dominada, que lhe proíbe de se erigir ao nível de ator ativo na construção do mundo.

Quando se trata do mundo árabe, é sempre perigoso generalizar, ignorando a diversidade das condições objetivas que caracterizam cada um dos países deste mundo. Portanto, centrarei as reflexões, a seguir, sobre o Egito, cujo papel é, sem objeção, reconhecido sempre como relevante na evolução geral da região.

O Egito foi o primeiro país da periferia do capitalismo globalizado que tentou emergir. Bem antes do Japão e da China, no início do século XIX, Muhammad Ali tinha concebido e levado a efeito um projeto de renovação do Egito e dos seus vizinhos imediatos do 


\section{temporolis}

AMIN, S. PRIMAVERA ÁRABE

Mashrek árabe. Esta experiência forte ocupou os dois terços do século XIX e se apagou somente na segunda metade do reino de Ismail Paxá, durante os anos 1870. A análise do seu fracasso não pode ignorar a violência da agressão externa da maior potência do capitalismo industrial central da época - a Grã-Bretanha. Duas vezes em 1840, depois nos anos 1870 (através da tomada do controle das finanças do Egito Kedival ${ }^{1}$ ) e, por último, pela ocupação militar (em 1882), a Inglaterra prosseguiu com obstinação o seu objetivo: impedir a emergência de um Egito moderno. Sem dúvida, o projeto egípcio conhecia limites, os que definiam a época, pois se tratava evidentemente de um projeto de emergência dentro e pelo capitalismo, ao contrário do projeto da segunda tentativa egípcia (1919-1967) sobre a qual retornarei. Decerto, as contradições sociais relativas a este projeto - como as concepções políticas, ideológicas e culturais sobre as quais ele se estendia - têm sua parte de responsabilidade neste fracasso. Mas, sem a agressão do imperialismo, essas contradições teriam provavelmente sido superadas, como o exemplo japonês o sugere.

Portanto, o Egito emergente vencido ficou submisso por quase quarenta anos (1880-1920) ao estatuto de periferia dominada, cujas estruturas foram reorganizadas para servir ao modelo da acumulação capitalista/imperialista da época. A regressão imposta atingiu, além do sistema produtivo do país, as suas estruturas políticas e sociais e também se pôs a reforçar sistematicamente concepções ideológicas e culturais passadistas e reacionárias úteis para a manutenção do país no seu estatuto subordinado.

\footnotetext{
${ }^{1}$ Kedive - título usado por Muhammad Ali Pasha e sua linha subsequente de sucessores dinásticos, que governou o Egito e Sudão, 1805-1914.
} 


\section{temporalis}

AMIN, S. PRIMAVERA ÁRABE

O Egito, ou seja, o seu povo, as suas elites, a nação que ele representa, nunca aceitou este estatuto. Tal recusa obstinada é, portanto, a origem de uma segunda onda de movimentos ascendentes que se estendeu durante o meio século seguinte (19191967). Com efeito, leio este período como um momento contínuo de lutas e de progressos importantes. O objetivo era triplo: democracia, independência nacional, progresso social. Estes três objetivos apesar das formulações limitadas e às vezes confusas - são inseparáveis uns dos outros. Esta interconexão dos objetivos é apenas a expressão dos efeitos da integração do Egito moderno no sistema do capitalismo/imperialismo globalizado da época. Nesta leitura, o capítulo aberto pela cristalização nasserista ${ }^{2}$ (1955-1967) é apenas o último capítulo deste longo momento do fluxo de progresso das lutas, inaugurado pela revolução de 1919-1920.

O primeiro momento deste meio século de amplificação das lutas de emancipação no Egito tinha colocado a tônica - com a constituição do Wafd, em $1919^{3}$ - na modernização política pela adoção de uma forma burguesa de democracia constitucional e sobre a reconquista da independência. A forma democrática imaginada permitia um progresso laicizante - senão laico no sentido radical do termo - cuja bandeira (que associa o crescente e a cruz - uma bandeira que fez sua reaparição nas manifestações de Janeiro e Fevereiro de 2011) constitui o símbolo. Eleições normais permitiam, então, não somente que os Coptas pudessem ser eleitos por maiorias muçulmanas, mas também pudessem exercer funções muito elevadas no Estado, sem que aquilo provocasse algum problema.

\footnotetext{
${ }^{2}$ Referência ao general Gamal Abdel Nasser.

3 Partido político.
}

Temporalis, Brasilia (DF), ano 10, n.20, p.221-252, jul./dez. 2010. 


\section{temporalis}

AMIN, S. PRIMAVERA ÁRABE

Todo o esforço da potência britânica - com o apoio ativo do bloco reacionário constituído pela monarquia, pelos grandes proprietários e pelos camponeses ricos - foi empregado para fazer recuar os progressos democráticos do Egito wafdista. A ditadura de Sedki Paxá, nos anos 1930 (abolição da constituição democrática de 1923), defrontou-se com o movimento dos estudantes, ferro de lança na época das lutas democráticas antiimperialistas. Não é por acaso que, para reduzir o perigo, a embaixada britânica e o Palácio real apoiaram ativamente a criação da Irmandade Muçulmana (1927) que se inspirava do pensamento islamista na sua versão salafista (passadista) wahhabista formulada por Rachid Reda, ou seja, a versão mais reacionária (antidemocrático e antiprogresso social) do novo Islã político.

Com a conquista da Etiópia, empreendida por Mussolini, e a perspectiva de uma guerra mundial se aproximando, Londres viuse obrigada a fazer concessões às forças democráticas, permitindo o regresso do Wafd, em 1936, e a assinatura do Tratado angloegípcio do mesmo ano - um Wafd ele mesmo ajuizado. A segunda guerra mundial, pela força das coisas, constituiu uma espécie de parêntese. Mas o fluxo de ampliação das lutas recomeçou a partir do dia 21 de Fevereiro de 1946, com a constituição do bloco estudante-operário, reforçado na sua radicalização pela entrada em cena dos comunistas e do movimento operário. Mais uma vez, as forças da reação egípcia apoiadas por Londres reagiram com violência e mobilizaram para esse efeito a Irmandade Muçulmana, que apoiou uma segunda ditadura de Sedki Pacha, sem conseguir fazer calar o movimento. O regresso do Wafd ao governo, a sua denúncia do Tratado de 1936 e o começo da guerrilha na zona do Canal ainda ocupada foram postos em xeque apenas pelo incêndio do Cairo (1951), uma operação na qual a Irmandade Muçulmana participou. 


\section{temporalis}

AMIN, S. PRIMAVERA ÁRABE

O primeiro golpe de Estado dos Oficiais livres (1952) e, sobretudo, o segundo que inaugura a tomada de controle de Nasser (1954) vieram para coroar este período de fluxo contínuo das lutas, segundo alguns, ou para pôr um fim, segundo outros. O nasserismo substituiu esta leitura que proponho do despertar egípcio por um discurso ideológico que suprime toda a história dos anos 1919-1952 para fazer iniciar a revolução egípcia no mês de Julho de 1952. À época, muitos entre os comunistas tinham denunciado este discurso e tinham analisado os golpes de Estado de 1952 e 1954 como destinados a pôr fim à radicalização do movimento democrático. Não estavam errados, porque 0 nasserismo se cristalizou como projeto antiimperialista apenas após Bandoung (Abril de 1955). O nasserismo então realizou o que podia dar: uma postura internacional resolutamente antiimperialista (associada aos movimentos pan-arábico e panafricano) e reformas sociais progressistas (mas não socialistas). Tudo vindo do alto, não somente sem democracia (proibindo às classes populares o direito de se organizar por elas mesmas e para elas mesmas), mas abolindo qualquer forma de vida política. O vazio criado chamava o Islã político a preenchê-lo. O projeto então esgotou o seu potencial de progressos num tempo curto - dez anos, de 1955 até 1965. A sufocação oferecia ao imperialismo, dirigido doravante pelos Estados Unidos, a oportunidade de quebrar o movimento, mobilizando para esse efeito o seu instrumento militar regional: Israel. A derrota de 1967 marca então o fim deste meio século de fluxos. O refluxo começou com Nasser - ele mesmo escolhendo a via das concessões à direita (o infitah, a abertura à globalização capitalista), de preferência à radicalização pela qual lutavam, entre outros, os estudantes (cujo movimento ocupa a dianteira da cena em 1970, pouco antes e após a morte de Nasser). Sadat, que sucede, acentua o alcance do desvio à direita e integra a Irmandade Muçulmana no seu novo sistema autocrático. Mubarak prossegue na mesma via.

Temporalis, Brasilia (DF), ano 10, n.20, p.221-252, jul./dez. 2010. 


\section{temporalis}

AMIN, S. PRIMAVERA ÁRABE

O período de refluxo sequente (1967-2011) cobre, por sua vez, quase meio século. O Egito, submisso às exigências do liberalismo globalizado e às estratégias dos Estados Unidos, cessou de existir como ator ativo regional e internacional. Na região, os aliados essenciais dos Estados Unidos - Arábia Saudita e Israel - ocupam a dianteira da cena. Israel pode então se empenhar na via da expansão da sua colonização da Palestina ocupada, com a cumplicidade tácita do Egito e dos países do Golfo.

O Egito de Nasser tinha instaurado um sistema econômico e social criticável, mas coerente. Nasser tinha apostado na industrialização para sair da especialização internacional colonial que confinava o país apenas à exportação de algodão. Este sistema assegurou uma distribuição dos rendimentos favorável às classes médias em expansão, sem empobrecimento das classes populares. Sadat e Mubarak empenharam-se no desmantelamento do sistema produtivo egípcio, ao qual substituíram um sistema totalmente incoerente, exclusivamente fundado sobre a procura da rentabilidade de empresas que, pela maior parte, são apenas subempreiteiros do capital dos monopólios imperialistas. As taxas de crescimento egípcias, supostamente elevadas e celebradas há 30 anos pelo Banco Mundial, carecem totalmente de significado. 0 crescimento egípcio é extremamente vulnerável. Este crescimento, além disso, acompanhou-se de um incrível aumento das desigualdades e do desemprego que atinge uma maioria de jovens. Esta situação, que se encontrava na iminência de seus limites, acabou irrompendo-se.

A aparente estabilidade do regime, que Washington elogiava, era fundada sobre uma máquina policial monstruosa (1.200.000 homens contra 500.000 apenas para o exército), que se entregava a abusos criminosos diários. As potências imperialistas afirmavam 


\section{temporalis}

AMIN, S. PRIMAVERA ÁRABE

que este regime protegia o Egito da alternativa islamita. Ora, trata-se apenas de uma mentira grosseira. Com efeito, o regime tinha integrado perfeitamente o Islã político reacionário (o modelo wahhabista do Golfo) no seu sistema de poder, concedendo-lhe a gestão da educação, da justiça e dos maiores meios de comunicação social (a televisão, particularmente). O único discurso autorizado era o das mesquitas confiadas aos Salafistas, permitindo-lhes, além disso, fingir constituir a oposição. A duplicidade cínica do discurso do establishment dos Estados Unidos (e nisso Obama não é diferente de Bush) serve perfeitamente aos seus objetivos. O apoio, de fato, ao Islã político destrói as capacidades da sociedade de fazer face aos desafios do mundo moderno (ele é a origem do declínio catastrófico da educação e da pesquisa), enquanto a denúncia ocasional de abusos dos quais é responsável (assassinatos de Coptas ${ }^{4}$, por exemplo) serve para legitimar as intervenções militares de Washington, comprometido com a suposta guerra contra o terrorismo. O regime podia parecer tolerável enquanto funcionava a válvula de segurança que representava a emigração maciça dos pobres e das classes médias para os países petroleiros. O esgotamento deste sistema (os imigrantes asiáticos substituíram os provenientes dos países árabes) provocou o renascimento das resistências. As greves operárias de 2007 (as mais fortes do continente africano, desde os últimos 50 anos), a resistência obstinada dos pequenos camponeses ameaçados de expropriação pelo capitalismo agrário e a formação de círculos de protesto democrático nas classes médias (os movimentos Kefaya e do 6 de Abril) anunciavam a inevitável explosão - esperada no Egito, ainda que tenha surpreendido os observadores estrangeiros. Entramos, portanto, numa fase nova de fluxos das lutas de emancipação, da qual

${ }^{4}$ Maior comunidade cristã no Egito.

Temporalis, Brasilia (DF), ano 10, n.20, p.221-252, jul./dez. 2010. 
devemos então analisar as direções e as possibilidades de desenvolvimento.

\section{OS COMPONENTES DO MOVIMENTO DEMOCRÁTICO}

A revolução egípcia em curso ilustra a possibilidade do fim anunciado do sistema neoliberal, reposto em causa em todas as suas dimensões políticas, econômicas e sociais. Este movimento gigantesco do povo egípcio associa três componentes ativos: os jovens repolitizados pela sua própria vontade e em formas modernas que inventaram, as forças da esquerda radical e aqueles reunidos pelas classes médias democratas.

Os jovens (cerca de um milhão de militantes) foram o ferro de lança do movimento. Foram imediatamente ajuntados pela esquerda radical e as classes médias democratas. A Irmandade Muçulmana - cujos líderes tinham pedido o boicote das manifestações durante os quatro primeiros dias (convencidos de que estas seriam derrotadas pela repressão) - aceitou o movimento apenas tardiamente, quando a chamada, entendida pelo conjunto do povo egípcio, produziu mobilizações gigantescas, em torno de 15 milhões de manifestantes.

Os jovens e a esquerda radical apontam três objetivos comuns: a restauração da democracia (o fim do regime militar e policial), a aplicação de uma nova política econômica e social favorável às classes populares (a ruptura com a submissão às exigências do liberalismo globalizado) e uma política internacional independente (a ruptura com a submissão às exigências da hegemonia dos Estados Unidos e do desdobramento do seu controle militar sobre o planeta). A revolução democrática é uma revolução democrática antiimperialista e social. Embora o movimento dos jovens fique diversificado no que tange sua composição social e suas 


\section{tempordils}

AMIN, S. PRIMAVERA ÁRABE

expressões políticas e ideológicas, ele situa-se principalmente à esquerda. As manifestações de simpatia espontâneas e fortes com a esquerda radical são o testemunho disso.

As classes médias unem-se principalmente em torno do único objetivo democrático, sem necessariamente repor em questão integralmente o mercado (como é) e o alinhamento internacional do Egito. Não se deve ignorar o papel de um grupo de bloguistas que participam - conscientemente ou não - de uma verdadeira conspiração organizada pela $\mathrm{CIA}$. Os seus animadores são geralmente jovens procedentes das classes favorecidas, americanizadas ao extremo, que se põem, entretanto, no papel de contestadores das ditaduras existentes. O tema da democracia, na versão que a sua manipulação por Washington impõe, domina as suas intervenções na rede. Participam consequentemente da cadeia dos atores das contrarrevoluções organizadas por Washington, disfarçadas em revoluções democráticas sobre o modelo das revoluções coloridas da Europa do Leste. Mas seria equivocado concluir que esta conspiração é a origem das revoltas populares. A ClA tenta, contudo, inverter o sentido do movimento, afastar os militantes dos seus objetivos de transformação social progressista e desviá-los para outros terrenos. As possibilidades de sucesso da conspiração se tornam sérias - se o movimento encalha na construção da convergência dos seus diversos componentes, falha em identificar objetivos estratégicos comuns e inventar formas de organização e de ação eficazes. Conhecemos exemplos deste fracasso, nas Filipinas e na Indonésia. É interessante notar a esse respeito que os nossos bloguistas - que se exprimem mais em inglês do que em árabe [!], partidos na defesa da democracia, à americana - desenvolvem frequentemente, no Egito, argumentos destinados a legitimar a Irmandade Muçulmana. 


\section{temporalis}

AMIN, S. PRIMAVERA ÁRABE

A chamada a manifestar, formulada pelos três componentes ativos do movimento, foi entendida rapidamente pelo conjunto do povo egípcio. A repressão - de uma violência extrema nos primeiros dias (mais de mil mortes) - não desencorajou estes jovens e os seus aliados (que, em nenhum momento, chamaram ao seu socorro as potências ocidentais como se pôde ver noutro lugar). A coragem foi o elemento decisivo que levou ao protesto, por meio dos bairros das grandes e das pequenas cidades ou mesmo das aldeias, uma quinzena de milhões de manifestantes durante dias e dias (e às vezes noites). Este sucesso político fulminante produziu efeitos: o medo mudou de campo; Hillary Clinton e Obama descobriram que era preciso largar Mubarak (que ambos apoiavam até então), enquanto os líderes do exército saíam do silêncio, pois recusavam participar do revezamento da repressão - salvaguardando, assim, a sua imagem - e, finalmente, depuseram Mubarak e alguns dos seus maiores sequazes.

A generalização do movimento ao conjunto do povo egípcio constitui em si um desafio positivo. Porque este povo está, como todos os outros, longe de constituir um bloco homogêneo. Alguns dos segmentos que o compõem reforçam inegavelmente a perspectiva de uma radicalização possível. A entrada na batalha da classe operária (cerca de 5 milhões de trabalhadores) pode ser decisiva. Os trabalhadores em luta (através de numerosas greves) fizeram progredir formas de organização começadas desde 2007.

Contam-se, doravante, mais de cinquenta sindicatos independentes. A resistência renhida dos pequenos camponeses contra as expropriações tornadas possíveis pela anulação da reforma agrária (a Irmandade Muçulmana votou no Parlamento para estas leis celeradas, sob pretexto de que a propriedade privada é consagrada no Islã e que a reforma agrária era inspirada pelo diabo comunista!) participa igualmente da radicalização 


\section{temporalis}

\section{AMIN, S. PRIMAVERA ÁRABE}

possível do movimento. O fato é que uma massa gigantesca de pobres participou ativamente nas manifestações de Fevereiro de 2011 e reencontra-se frequentemente nas comissões populares constituídas nos bairros para defender a revolução. Esses pobres podem dar a impressão (pelas barbas, pelos véus, pelos trajes) de que o país profundo é islamita, ou mesmo mobilizado pela Irmandade Muçulmana. Com efeito, sua entrada em cena impôsse à direção da organização. A corrida, portanto, é comprometida: quem da Irmandade e dos seus sócios islamitas (os Salafistas) ou da aliança democrática chegará a formular alianças eficazes com as massas desorientadas, ou mesmo enquadrá-las (palavra que recuso)?

Progressos significativos na construção da frente unida das forças democráticas e dos trabalhadores estão em curso no Egito. Cinco partidos de orientação socialista - o Partido Socialista Egípcio, a Aliança Popular Democrática (uma maioria saída do antigo partido do Tagammu), o Partido Democrático dos Trabalhadores, o Partido dos Socialistas Revolucionários (trotskista) e o Partido Comunista Egípcio (que tinha sido um componente do Tagammu) constituíram no mês de Abril de 2011 uma Aliança das forças socialistas e comprometeram-se a prosseguir, através dela, com suas lutas em comum. Paralelamente, um Conselho Nacional (Maglis Watany) foi constituído por todas as forças políticas e sociais protagonistas do movimento (os partidos de orientação socialista, os diversos partidos democráticos, os sindicatos independentes, as organizações campesinas, as redes de jovens, numerosas associações sociais). A Irmandade Muçulmana e os partidos de direita recusaram participar deste Conselho, reafirmando, assim, o que se sabe: a sua oposição à continuação do movimento. O Conselho reúne cerca de 150 membros. 


\section{temporollis}

AMIN, S. PRIMAVERA ÁRABE

\section{PERANTE O MOVIMENTO DEMOCRÁTICO: O BLOCO REACIONÁRIO}

Da mesma maneira que no período de fluxo das lutas do passado, o movimento democrático antiimperialista e social choca-se no Egito com um bloco reacionário potente. Este bloco pode ser identificado nas expressões de seus componentes sociais (de classes, evidentemente), mas também nas expressões que definem os seus meios de intervenção política e discursos ideológicos ao serviço dela.

Em termos sociais, o bloco reacionário é dirigido pela burguesia egípcia considerada no seu conjunto. As formas de acumulação dependente trabalhando durante os 40 últimos anos produziram o surgimento de uma burguesia rica, beneficiária exclusiva da desigualdade escandalosa que acompanhou este modelo liberalglobalizado. Não se trata de dezenas de milhares de empresários inventivos - como o discurso do Banco Mundial os apresenta -, mas sim de milionários e bilionários que devem sua fortuna ao conluio que têm com o aparelho político (a corrupção é um componente orgânico deste sistema). Esta burguesia é compradora (na língua política corrente no Egito, o povo a qualifica de parasitas corrompidos). Constitui o apoio ativo da inserção do Egito na globalização imperialista contemporânea, o aliado incondicional dos Estados Unidos. Esta burguesia conta em seus círculos com um grande número de generais do exército e da polícia, de civis associados ao Estado e ao partido dominante (Nacional Democrático) criado por Sadat e Mubarak e de religiosos (a totalidade dos líderes da Irmandade Muçulmana e dos maiores xeques da Azhar, todos bilionários). Claro que existe ainda uma burguesia de pequenos e médios empresários ativos. Mas aqueles são as vítimas do sistema de extorsão instaurado pela burguesia compradora, confinados geralmente ao estatuto de subempreiteiros dominados pelos monopólios locais - eles 


\section{tempordilis}

\section{AMIN, S. PRIMAVERA ÁRABE}

próprios equivalem a correias de transmissão dos monopólios estrangeiros. No domínio da construção, esta situação é quase generalizada: os gordos fazem uma razia ${ }^{5}$ nos mercados e depois os terceirizam com os pequenos. Esta burguesia de empresários autênticos simpatiza com o movimento democrático.

A vertente rural do bloco reacionário não é menos importante. Constituiu-se de camponeses ricos que foram os maiores beneficiários da reforma agrária nasseriana, os quais foram substituídos pela antiga classe dos grandes proprietários. As cooperativas agrícolas instauradas pelo regime nasseriano associavam os pequenos camponeses aos camponeses ricos e, como isso, funcionavam principalmente em benefício dos ricos. Mas o regime tinha tomado precauções para limitar as agressões possíveis contra os pequenos camponeses. Com tais precauções sendo abandonadas por Sadat e Mubarak, sob recomendação do Banco Mundial, o campesinato rico emprega-se agora para acelerar a eliminação do pequeno campesinato. Os camponeses ricos sempre constituíram no Egito moderno uma classe reacionária, o que, mais que nunca, é verdadeiro. São igualmente os maiores apoios do Islã conservador nas campanhas e, pelas suas relações estreitas (frequentemente de parentesco) com os representantes dos aparelhos de Estado e da religião (a Azhar é no Egito o equivalente de uma Igreja muçulmana organizada), dominam a vida social rural. Além disso, uma boa parte das classes médias urbanas (em especial, oficiais do exército e da polícia, mas também os tecnocratas e as profissões liberais) saiu diretamente do campesinato rico.

\footnotetext{
${ }^{5}$ Palavra de origem argelina que significa "[...] invasão predatória em território inimigo, saque. No sentido figurado, indica destruição, devastação [...]”.
}

Temporalis, Brasilia (DF), ano 10, n.20, p.221-252, jul./dez. 2010. 


\section{temporalis}

AMIN, S. PRIMAVERA ÁRABE

Este bloco social reacionário dispõe de instrumentos políticos ao seu serviço: o exército e a polícia, as instituições do Estado, o partido político privilegiado (uma espécie de partido único de fato) - o Partido Nacional Democrático criado por Sadat -, o aparelho religioso (a Azhar), as correntes do Islã político (a Irmandade Muçulmana e os Salafistas). A ajuda militar concedida pelos Estados Unidos ao exército egípcio (1,5 bilhões de dólares anuais) nunca foi destinada a reforçar a capacidade de defesa do país, mas, ao contrário, a destruir o perigo dela pela corrupção sistemática, não somente conhecida e tolerada, mas apoiada positivamente, com cinismo. Esta ajuda permitiu aos mais altos oficiais apropriarse de importantes segmentos da economia compradora egípcia, de tal maneira que se fala no Egito da sociedade anônima/armada (Sharika al geish). O comando do exército, que tomou a responsabilidade de dirigir o período de transição, não é, portanto, neutro, embora tenha tomado a precaução de parecer sê-lo, dissociando-se da repressão. O governo civil às suas ordens (cujos membros foram nomeados pelo alto comando), composto por parte de homens do antigo regime (escolhidos, no entanto, entre as personalidades menos visíveis deste), tomou uma série de medidas perfeitamente reacionárias destinadas a travar a radicalização do movimento. Entre essas medidas, uma lei celerada antigreve (sob pretexto de repor em funcionamento a economia do país), uma lei que impõe restrições severas à constituição dos partidos políticos e que visa a permitir a possibilidade de entrar no jogo eleitoral apenas para os do Islã político (a Irmandade Muçulmana em especial), já bem organizados graças ao apoio sistemático do antigo regime. E, assim, apesar de tudo isso, a atitude do exército fica, em última instância, imprevisível. Isso porque, embora se reconheça a corrupção em seus quadros (os soldados são conscritos, mas os oficiais são profissionais), o sentimento nacionalista não está ausente em todos. Além disso, o exército sofre por ter sido quase afastado do poder em proveito da 


\section{tempordils}

AMIN, S. PRIMAVERA ÁRABE

polícia. Nestas circunstâncias, e levando em conta que o movimento exprimiu com força a sua vontade de afastar o exército da direção política do país, é provável que o alto comando considere para o futuro permanecer nos bastidores, renunciando a apresentar seus homens nas eleições que estão por vir.

Se, evidentemente, o aparelho policial fica intacto (nenhum processo é encarado contra os seus responsáveis), assim como o conjunto do aparelho de Estado (todos os novos governadores são antigos do regime), o Partido Nacional Democrático em contrapartida desapareceu na tormenta e a sua dissolução foi pronunciada pela justiça. No entanto, podemos ter confiança na burguesia egípcia, pois ela saberá fazer reaparecer o seu partido sob diversas novas denominações.

\section{O ISLÃ POLÍTICO}

A Irmandade Muçulmana corresponde à única força política que o regime não havia somente tolerado a sua existência, mas também apoiado ativamente o seu desenvolvimento. Sadat e Mubarak tinham-lhe entregue a gestão de três instituições fundamentais: a educação, a justiça e a televisão. A Irmandade Muçulmana nunca foi e não pode ser moderada, e menos ainda democrática. O seu chefe - o mourchid (tradução árabe de guia) - é autoproclamado e a organização funda-se à luz do princípio da disciplina e da execução das ordens dos chefes, sem possibilidade de discutir. Daí verifica-se que: a direção é constituída exclusivamente por homens extremamente ricos (graças, entre outras coisas, ao apoio financeiro da Arábia Saudita, quer dizer de Washington); o enquadramento por homens procedentes das frações obscurantistas das classes médias; a base por pessoas do povo recrutadas pelos serviços sociais de caridade oferecidos pela confraria (e financiados sempre pela Arábia Saudita); e, por fim, o

Temporalis, Brasilia (DF), ano 10, n.20, p.221-252, jul./dez. 2010. 


\section{temporalis}

AMIN, S. PRIMAVERA ÁRABE

braço armado é constituído pelas milícias (os baltaguis) recrutadas no lúmpen.

A Irmandade Muçulmana é fiel a um sistema econômico baseado no mercado e totalmente dependente do exterior. Ela é, com efeito, um componente da burguesia compradora. Aliás, tomou posição contra as grandes greves da classe operária e as lutas dos camponeses para conservar a propriedade das suas terras. A Irmandade Muçulmana é, portanto, moderada na medida em que sempre recusou formular um programa econômico e social qualquer - o que, por um lado, não repõe em causa as políticas neoliberais reacionárias e, por outro, aceita a submissão às exigências do desdobramento do controle dos Estados Unidos no mundo e na região. Ela é, portanto, um aliado útil para Washington que lhe concedeu um "certificado de democracia"! (A propósito, será que existe um melhor aliado para os Estados Unidos do que a Arábia Saudita, proprietária da Irmandade?).

Mas os Estados Unidos não podem confessar que a sua estratégia visa a instaurar regimes islâmicos na região. Precisam fazer como se "[...] aquilo lhes desse medo [...]". Desse modo, legitimam sua "[...] guerra permanente ao terrorismo [...]", que tem realmente outros objetivos: um controle militar do planeta destinado a reservar ao conjunto Estados Unidos-Europa-Japão o acesso exclusivo aos recursos. Vantagem suplementar desta duplicidade: permite mobilizar a islamofobia das opiniões públicas. A Europa, como se sabe, não tem estratégia específica em relação à região e se satisfaz em alinhar-se no dia a dia com as decisões de Washington. Mais do que nunca é necessário fazer aparecer claramente esta verdadeira duplicidade da estratégia dos Estados Unidos, cujas opiniões públicas - manipuladas com eficácia deixam-se lograr muito ingenuamente. Os Estados Unidos (e, por trás deles, a Europa) temem sobremaneira um Egito realmente 


\section{temporalis}

AMIN, S. PRIMAVERA ÁRABE

democrático, o que, certamente, reporia em discussão o seu alinhamento sobre o liberalismo econômico e a estratégia agressiva dos Estados Unidos e da Organização do Tratado do Atlântico Norte (OTAN). Farão tudo de modo que o Egito não seja democrático e, para esse efeito, apoiarão por todos os meios - mas com hipocrisia - a falsa alternativa que encarna a Irmandade Muçulmana, a qual mostrou ser minoria no movimento do povo egípcio para uma mudança real.

O conluio entre as potências imperialistas e o Islã político não é novo, nem específico ao Egito. A Irmandade Muçulmana, desde a sua criação em 1927 até o presente, sempre foi um tipo de aliado útil ao imperialismo e ao bloco reacionário local. Sempre foi um inimigo feroz dos movimentos democráticos no Egito. E os multibilionários que asseguram hoje a direção da Confraria não são destinados a aderir à causa democrática! O Islã político é igualmente o aliado estratégico dos Estados Unidos e dos seus parceiros subalternos da OTAN através do mundo muçulmano. Washington armou e financiou os Talebãs, qualificados como "heróis da liberdade" (Freedom Fighters) na sua guerra contra o regime nacional popular dito "comunista" (antes e após a intervenção soviética). Quando os Talebãs fecharam as escolas femininas criadas pelos comunistas, democratas e feministas foram encontrados a fim de defender a ideia de que era necessário “[...] respeitar as tradições [...]"!

No Egito, a Irmandade Muçulmana é doravante ajudada pela corrente salafista (tradicionalista), também largamente financiada pelos países do Golfo. Os Salafistas afirmam-se extremistas (wahhabistas convencidos, intolerantes em relação a qualquer outra interpretação do Islã) e são a origem dos assassinatos sistemáticos perpetrados contra os Coptas. Operações difíceis a imaginar sem o apoio tácito (e às vezes com mais cumplicidade) do aparelho do Estado, em especial da 


\section{temporalis}

AMIN, S. PRIMAVERA ÁRABE

Justiça, largamente confiada à Irmandade Muçulmana. Esta estranha divisão do trabalho permite à Irmandade Muçulmana parecer moderada - o que Washington finge acreditar. Há, no entanto, lutas violentas em perspectiva nas correntes religiosas islamitas no Egito. Porque o Islã egípcio histórico dominante é sufi, cujas confrarias reúnem hoje 15 milhões de fiéis. Islã aberto, tolerante, insistindo sobre a convicção individual mais que sobre a prática ritual ("[...] há tantas vias para chegar a Deus quantos indivíduos [...]"), o sufismo egípcio sempre foi considerado suspeito pelos poderes de Estado, os quais, no entanto, manipulando cenouras e paus, se guardavam de entrar em guerra aberta contra ele. O Islã wahhabista do Golfo contrapõe-se aos antípodas do sufismo: é arcaico, ritualista, conformista, inimigo declarado de qualquer interpretação outra que não a sua, a qual é repetitiva em textos, inimiga de qualquer espírito crítico - assimilado ao Diabo. O Islã wahhabista declarou guerra ao sufismo que ele quer extirpar e tem o apoio das autoridades do poder para conseguir. Em reação, os sufistas de hoje estão laicizantes, se não são laicos; pedem a separação entre a religião e a política (o poder de Estado e o das autoridades religiosas reconhecidas por ele, a Azhar). Os sufistas são aliados do movimento democrático. O Islã wahhabista no Egito foi introduzido por Rachid Reda nos anos 1920 e foi recuperado pela Irmandade Muçulmana a partir de 1927. Mas ele adquiriu todo seu vigor somente após a segunda guerra mundial quando a renda petroleira dos países do Golfo, apoiados pelos Estados Unidos em conflito com a onda de libertação nacional popular dos anos 1960, permitiu multiplicar os meios financeiros.

\section{A ESTRATÉGIA DOS ESTADOS UNIDOS: O MODELO PAQUISTANÊS}

As três potências que dominaram a cena meio-oriental durante todo o período de refluxo (1967-2011) são os Estados Unidos (dono do sistema), Arábia Saudita e Israel. Trata-se de três aliados íntimos. Compartilham o mesmo medo da emergência de um Egito 


\section{temporalis}

AMIN, S. PRIMAVERA ÁRABE

democrático. Porque esta só poderia ser antiimperialista e social, tomaria as suas distâncias em relação ao liberalismo globalizado, condenaria a Arábia Saudita e os países do Golfo à insignificância, reativaria a solidariedade dos povos árabes e imporia o reconhecimento do Estado palestino por Israel.

O Egito é uma pedra angular na estratégia dos Estados Unidos de controle do planeta. O objetivo exclusivo de Washington e dos seus aliados, Israel e Arábia Saudita, é fazer abortar o movimento democrático no Egito e, para esse efeito, querem impor um regime islâmico dirigido pela Irmandade Muçulmana, que é o único meio para eles de perpetuar a submissão do Egito. O discurso democrático de Obama serve apenas para enganar as opiniões ingênuas, as dos Estados Unidos e da Europa em primeiro lugar.

Fala-se muito do exemplo turco, para dar uma legitimidade a um governo da Irmandade Muçulmana (aderida à democracia!). Porém, mais uma vez, trata-se apenas de poeira nos olhos. Porque o exército turco, que fica nos bastidores, embora certamente não democrático e, além disso, um aliado fiel da OTAN, permanece com a garantia da laicidade na Turquia. O projeto de Washington, abertamente expresso por Hillary Clinton, Obama e os think tanks ao seu serviço, inspira-se do modelo paquistanês: o exército (islâmico) nos bastidores, o governo (civil) assumido por um (ou uns) partido(s) islâmico(s) eleito(s). Evidentemente, nesta hipótese, o governo islâmico egípcio seria recompensado pela sua submissão sobre o essencial (a não recolocação em causa do liberalismo e dos supostos tratados de paz que permitem a Israel a continuação da sua política de expansão territorial) e poderia prosseguir, em compensação demagógica, com a aplicação dos seus projetos de islamização do Estado e da política e os assassinatos de Coptas! Que bonita esta democracia concebida em Washington para o Egito! A Arábia Saudita apoia evidentemente 


\section{temporolis}

AMIN, S. PRIMAVERA ÁRABE

com todos os meios (financeiros) a aplicação deste projeto. Porque Riade sabe perfeitamente que a sua hegemonia regional (no mundo árabe e muçulmano) exige a redução do Egito à insignificância. E o meio é a "islamização do Estado e da política"; de fato, uma islamização à wahhabista, com todos os seus efeitos dentre os quais, o de inclinações fanáticas em relação aos Coptas e de uma negação dos direitos à igualdade das mulheres.

Esta forma de islamização é possível? Talvez, mas ao preço de violências extremas. A batalha é conduzida em volta do artigo $2 \mathrm{da}$ constituição do regime caído. Este artigo que estipula que "[...] a charia é a fonte do direito [...]”, é uma novidade na história política do Egito. Nem a constituição de 1923, nem a de Nasser o tinham imaginado. É Sadat que o introduziu na sua nova constituição, com o apoio triplo de Washington (“[...] respeitar as tradições! [...]”), de Riade (o Alcorão serve de Constituição) e de Jerusalém (o Estado de Israel é um Estado judaico).

O projeto da Irmandade Muçulmana visa à instauração de um Estado teocrático, como testemunha o seu apego ao artigo 2 da Constituição de Sadat/Mubarak. Além disso, o programa mais recente da organização reforça ainda essa visão passadista pela proposta de instaurar um Conselho dos Ulemás encarregado de vigiar a conformidade de qualquer proposta de lei às exigências da Charia. Este conselho constitucional religioso é o análogo do que, no Irã, controla o poder eleito. Portanto, o regime é o de um superpartido religioso único e todos os partidos que se afirmariam laicos tornar-se-iam ilegais. Os seus partidários, como os não Muçulmanos (os Coptas) seriam de fato excluídos da vida política. Apesar disso, os poderes em Washington e na Europa fingem acreditar na recente declaração da Irmandade que renuncia ao projeto teocrático (sem alterar o seu programa!) - mais uma declaração oportunista e enganosa. Mas os peritos da CIA não 


\section{temporalis}

AMIN, S. PRIMAVERA ÁRABE

sabem, portanto, ler o árabe? A conclusão impõe-se: Washington prefere o poder da Irmandade, que lhes garante a manutenção do Egito na sua zona de influência e no seio da globalização liberal, em vez do poder de democratas que poderiam seriamente colocar em questão o estatuto subalterno do Egito. O Partido da Justiça e da Liberdade, criado recentemente e inspirado visivelmente pelo modelo turco, é apenas um instrumento da Irmandade. Os Coptas seriam admitidos nele [!], o que significa que são convidados a aceitar o Estado muçulmano teocrático consagrado pelo programa da Irmandade, se querem ter o direito de participar na vida política do seu país. Indo à ofensiva, a Irmandade Muçulmana cria sindicatos, organizações campesinas e um rancho de partidos políticos com nomes diversos, cujo único objetivo é dividir as frentes unidas operárias, campesinas e democráticas em via de construção, em benefício, naturalmente, do bloco contrarrevolucionário.

O movimento democrático egípcio será capaz de revogar este artigo na nova constituição por vir? Pode-se responder a tal pergunta apenas por um regresso a um exame dos debates políticos, ideológicos e culturais que se estenderam na história do Egito moderno.

Constata-se, com efeito, que os períodos de fluxos são caracterizados por uma diversidade de opiniões abertamente expressas que relegam a religião (sempre presente na sociedade) ao segundo plano. Foi assim durante os dois terços do século XIX (de Muhammad Ali ao Quediva Ismail). Os temas da modernização (numa forma de despotismo iluminado, mas não democrático) dominam então a cena. Da mesma maneira foi de 1920 até 1970: a confrontação é aberta entre os democratas burgueses e os comunistas que ocupam largamente a dianteira da cena até o nasserismo. Este debate é abolido pelo nasserismo para introduzir

Temporalis, Brasilia (DF), ano 10, n.20, p.221-252, jul./dez. 2010. 


\section{temporalis}

AMIN, S. PRIMAVERA ÁRABE

um discurso populista. Pan-árabe, mas simultaneamente modernizante. As contradições deste sistema abrem o caminho ao regresso do Islã político. Constata-se, em contrapartida, que nas fases de refluxo a diversidade de opiniões apaga-se, deixando o lugar ao suposto passadismo islâmico, em que se outorga o monopólio do discurso autorizado pelo poder. De 1880 até 1920, os Britânicos construíram este desvio, entre outras coisas, pela condenação ao exílio (na Núbia, principalmente) dos pensadores e atores modernistas egípcios formados desde Muhammad Ali. Mas observar-se-á também que a oposição a tal ocupação britânica fica igualmente nesta concepção passadista. A Nahda (inaugurada por Jamal al-Din al-Afghani e prosseguido por Muhammad Abduh) inscreve-se neste desvio, associado à ilusão otomanista defendida pelo novo Partido Nacionalista de Mustafa Kemal e Muhammad Farid. Que tal fato conduziu, no final da época, aos escritos ultrarreacionários de Rachid Reda, retomados por Hassan al Banna, fundador da Irmandade Muçulmana, não deveria causar surpresa.

É do mesmo modo mais uma vez no período de refluxo dos anos 1970-2010. O discurso oficial do poder (de Sadat e Mubarak), perfeitamente islamita (a prova: a introdução da Charia na constituição e a delegação de poderes relevantes à Irmandade Muçulmana), é também o da falsa oposição, a única tolerada, a do discurso das mesquitas. Portanto, o artigo 2 pode parecer firmemente ancorado na convicção geral (a rua como se agrada dizer, por imitação do discurso dos Estados Unidos). É preciso não subestimar os efeitos devastadores da despolitização levada a efeito sistematicamente durante os períodos de refluxo. A inclinação não é nunca fácil de tornar a subir. Mas isto não é impossível. Os debates em curso no Egito são centrados - explicita ou implicitamente - sobre essa pergunta da suposta dimensão cultural do desafio (neste caso islâmico). Indicadores positivos: algumas semanas de debates livres impostos pelos fatos foram 


\section{temporalis}

AMIN, S. PRIMAVERA ÁRABE

suficientes para ver o slogan [...] o Islã é a solução [...]" desaparecer de todas as manifestações em benefício de reivindicações precisas sobre o terreno da transformação concreta da sociedade (liberdade de opinião, formação de partidos, sindicatos e outras organizações sociais, salários e direitos do trabalho, acessos à terra, escola e saúde, rejeição das privatizações e chamada às nacionalizações). Um sinal que não engana: nas eleições dos estudantes, a Irmandade Muçulmana, que há cinco anos ganhou com uma esmagadora maioria (80\%) dos votos (só o discurso dela era aceito como pretendida oposição), sofreu uma derrota nas eleições de Abril (20\%!). Mas o adversário sabe igualmente organizar a resposta ao perigo democrático. As modificações insignificantes da constituição (sempre em vigor!) propostas por uma Comissão constituída exclusivamente de islamitas escolhidos pelo conselho supremo (o exército) e adotadas às pressas em Abril por referendo (23\% de não, mas uma maioria de sim forçada pelas fraudes e uma chantagem maciça das mesquitas) não se referem evidentemente ao artigo 2. Eleições presidenciais e legislativas estão previstas para Setembro/Outubro de 2011. O movimento democrático parte para uma transição democrática mais longa, de maneira a permitir aos seus discursos atingir verdadeiramente as massas desamparadas. Mas Obama escolheu desde os primeiros dias da insurreição: uma transição curta, ordenada (ou seja, sem recolocar em causa os aparelhos do regime) e eleições (dando uma vitória desejada aos islamitas). As eleições, como se sabe, no Egito como noutro lugar no mundo, não são o melhor meio para fundar a democracia, mas frequentemente o de pôr um termo à dinâmica dos progressos democráticos.

Uma última palavra relativa à corrupção. O discurso dominante do regime de transição insiste sobre a sua denúncia, associada a ameaças de processos judiciais (veremos o que acontecerá de fato). Com certeza, este discurso é bem-recebido, em especial pela 


\section{temporalis}

AMIN, S. PRIMAVERA ÁRABE

fração, provavelmente maior, da opinião ingênua. Mas evita-se analisar as razões profundas e fazer compreender que a corrupção (apresentada como um desvio moral, do tipo do discurso moralizante dos Estados Unidos) é um componente orgânico necessário para a formação da burguesia. Não somente no caso do Egito e dos países do Sul, em geral, tratando-se da formação de uma burguesia compradora cuja associação aos poderes do Estado constitui o único meio para a sua emergência. Afirmo que na fase do capitalismo dos monopólios generalizados, a corrupção tornouse um elemento constitutivo orgânico da reprodução do modelo de acumulação: a captação de uma parte da renda dos monopólios exige a cumplicidade ativa do Estado. O discurso ideológico ("o vírus liberal") proclama o não-Estado, ao passo que a sua prática é "[...] o Estado ao serviço dos monopólios".

\section{A ZONA DAS TEMPESTADES}

Mao não estava errado quando afirmava que o capitalismo (realmente existente, quer dizer, imperialista por natureza) não tinha nada a oferecer aos povos dos três continentes (a periferia constituída pela Ásia, pela África e pela América Latina - esta minoria que reúne $85 \%$ da população do planeta!) e que, por conseguinte, o Sul constituía a zona das tempestades, isto é, das revoltas repetidas, potencialmente (mas apenas potencialmente) portadoras de progressos revolucionários em direção à superação socialista do capitalismo.

A primavera árabe inscreve-se nesta realidade. Trata-se de revoltas sociais potencialmente portadoras da cristalização de alternativas, que podem em longo prazo inscrever-se na perspectiva socialista. É a razão pela qual o sistema capitalista, o capital dos monopólios dominantes à escala mundial, não pode tolerar o desenvolvimento destes movimentos. Mobilizará todos os meios de desestabilização 


\section{tempordils}

AMIN, S. PRIMAVERA ÁRABE

possíveis, das pressões econômicas e financeiras até a ameaça militar. Apoiará, de acordo com as circunstâncias, sejam as alternativas fascistas ou fascizantes, seja a instauração de ditaduras militares. Não se deve crer em uma palavra que diz Obama. Obama é Bush, mas com uma outra linguagem. Há uma duplicidade permanente na linguagem dos líderes da tríade imperialista (Estados Unidos, Europa ocidental, Japão).

Não tenho a intenção aqui de examinar com tanta precisão cada um dos movimentos em curso no mundo árabe (Tunísia, Líbia, Síria, lêmen e outros). Porque os componentes do movimento são diferentes de um país a outro, da mesma maneira que o são as formas da sua integração na globalização imperialista e as estruturas dos regimes existentes.

A revolta tunisiana deu o sinal e certamente incentivou fortemente os egípcios. Além disso, o movimento tunisiano se beneficia de uma certa vantagem: a meia laicidade introduzida por Bourguiba não poderá provavelmente ser reposta em causa pelos islamitas retornados do exílio na Grã-Bretanha. Mas simultaneamente o movimento tunisiano não parece estar em condições de recolocar em questão o modelo de desenvolvimento aberto, inscrito na globalização capitalista liberal.

A Líbia não é nem a Tunísia, nem o Egito. O bloco no poder (Muammar al-Gaddafi) e as forças que lutam contra ele não têm nada a ver com os da Tunísia e do Egito. Gaddafi sempre foi apenas um polichinelo cujo vazio do pensamento encontra o seu reflexo no seu famoso Livro verde. Operando numa sociedade ainda arcaica, Gaddafi podia permitir-se ter discursos sucessivos - sem grande alcance real - nacionalistas e socialistas e depois aderir ao liberalismo. Fê-lo "[...] para satisfazer os Ocidentais" [!], como se a escolha do liberalismo não tivesse efeitos na sociedade. Ora, teve 


\section{temporalis}

AMIN, S. PRIMAVERA ÁRABE

e, muito banalmente, agravou as dificuldades sociais para a maioria. As condições então criadas deram a explosão que se conhece, imediatamente aproveitada pelo Islã político do país e pelos regionalismos. Porque a Líbia nunca realmente existiu como nação. É uma região geográfica que separa o Magrebe e o Mashrek. A fronteira entre os dois passa precisamente no meio da Líbia. A Cirenaica é historicamente grega e helenística, e depois se tornou mashrequina. A Tripolitânia foi latina e tornou-se magrebina. Portanto, sempre houve uma base para regionalismos no país. Não se sabe quem são realmente os membros do Conselho nacional de transição de Bengasi. Há, talvez, democratas entre eles, mas também há, certamente, islamitas (e os piores deles) e regionalistas. Desde o início, o movimento tomou na Líbia a forma de uma revolta armada, fazendo fogo sobre o exército, e não a de uma onda de manifestações civis. Além disso, esta revolta armada chamou imediatamente a OTAN ao seu socorro. A oportunidade então era dada para uma intervenção militar das potências imperialistas. Com certeza, o objetivo apontado não é a proteção dos civis, nem a democracia, mas o controle do petróleo e a aquisição de uma base militar essencial no país. Certamente, as companhias ocidentais controlavam já o petróleo líbio, desde a adesão de Gaddafi ao liberalismo. Mas com Gaddafi nada está certo. E se mudasse de ideia e se introduzisse amanhã no seu jogo os Chineses ou os Indianos? Contudo, há algo mais grave. Gaddafi tinha exigido a partir de 1969 a evacuação das bases britânicas e dos Estados Unidos instaladas depois da segunda guerra mundial. Hoje, os Estados Unidos precisam transferir o Africom (o comando militar dos Estados Unidos para a África, uma peça importante do dispositivo de controle militar do planeta, ainda localizado em Stuttgart!) para a África. Ora, a União Africana recusa aceitá-lo e até agora nenhum Estado africano ousou fazê-lo. Um lacaio colocado em posto em Trípoli (ou em Bengasi) subscreveria 


\section{tempordils}

AMIN, S. PRIMAVERA ÁRABE

evidentemente todas as exigências de Washington e de seus aliados subalternos da OTAN.

Os componentes da revolta na Síria não têm até agora indicado os seus programas. Sem dúvida, o desvio do regime baathista, aderido ao neoliberalismo e singularmente passivo perante a ocupação das Colinas de Golã por Israel, é a origem da explosão popular. Mas não se pode excluir a intervenção da CIA: fala-se de grupos que penetraram em Diraa proveniente da Jordânia vizinha. A mobilização da Irmandade Muçulmana que, há alguns anos, tinha sido a origem das revoltas de Hama e de Homs talvez não seja estrangeira à conspiração de Washington, que se emprega a pôr um fim à aliança entre Síria e Irã, indispensável para o apoio do Hizbollah, no Líbano, e do Hamas, em Gaza.

No lêmen, a unidade tinha-se construído sobre a derrota das forças progressistas que tinham governado o Sul do país. Será que o movimento vai devolver a essas forças sua vitalidade? Por esta razão, entendem-se as hesitações de Washington e do Golfo.

No Bahrein, a revolta foi abafada no início pela intervenção do exército saudita e o massacre, sem que as mídias dominantes fizessem a mera objeção. Dois pesos, duas medidas, como sempre.

A revolta árabe não constitui o único exemplo, mas é a expressão mais recente da instabilidade inerente à zona das tempestades.

Uma primeira onda de revoluções, por assim falar, tinha varrido certas ditaduras na Ásia (as Filipinas, a Indonésia) e na África (o Mali), que tinham sido instauradas pelo imperialismo e os blocos reacionários locais. Mas, nestes casos, os Estados Unidos e a Europa tinham conseguido fazer abortar a dinâmica dos movimentos populares, às vezes gigantescos pelas mobilizações 


\section{temporolis}

AMIN, S. PRIMAVERA ÁRABE

que suscitaram. Os Estados Unidos e a Europa querem repetir no mundo árabe o que aconteceu no Mali, nas Filipinas e na Indonésia: alterá-lo para que não altere nada! Nestes países, depois que os movimentos populares eliminaram os seus ditadores, as potências imperialistas empregaram-se a preservar $o$ essencial pela instauração de governos alinhados sobre o neoliberalismo e os interesses da sua política externa. É interessante constatar que nos países muçulmanos (Mali, Indonésia) o Islã político foi mobilizado para esse efeito.

A onda dos movimentos de emancipação que varreu a América do Sul permitiu, ao contrário, progressos reais nas três direções que representam a democratização do Estado e da sociedade, a adoção de posturas antiimperialistas importantes, o compromisso em favor de reformas sociais progressistas.

O discurso dominante das mídias compara as revoltas democráticas do terceiro mundo com as que puseram um fim aos socialismos da Europa oriental depois da queda do muro de Berlim. Trata-se de uma fraude pura e simples. Porque quaisquer que fossem as razões (compreensíveis) das revoltas em questão, estas se inscreviam na perspectiva da anexação da região pelas potências imperialistas da Europa do Oeste (ao benefício da Alemanha em primeiro lugar). De fato, reduzidos doravante ao estatuto de periferias da Europa capitalista desenvolvida, os países da Europa oriental conhecerão amanhã a sua revolta autêntica. Já existem os sinais anunciadores, na ex-lugoslávia em especial.

Pode-se prever revoltas, potencialmente portadoras de progressos revolucionários, por toda parte ou quase nos três continentes, que permanecem, mais do que nunca, na zona das tempestades, desmentindo os discursos adocicados sobre o capitalismo eterno e a estabilidade, a paz, o progresso democrático que se lhe associa. 


\section{tempordils}

AMIN, S. PRIMAVERA ÁRABE

Mas essas revoltas, para tornarem-se progressos revolucionários, deverão superar numerosos obstáculos: por um lado, superar as fraquezas do movimento, construir convergências positivas entre os seus componentes, conceber e levar a efeito estratégias eficazes, mas, por outro, derrotar as intervenções (militares incluídas) da tríade imperialista. Porque qualquer intervenção militar dos Estados Unidos e da OTAN nos assuntos dos países do Sul, sob algum pretexto, mesmo que pareça simpática - como a intervenção humanitária -, deve ser proscrita. O imperialismo não quer nem o progresso social, nem a democracia para estes países. Os lacaios que ele coloca no poder quando ganha a batalha permanecerão inimigos da democracia. Pode-se lamentar que a esquerda européia, mesmo radical, cessou de entender o que é o imperialismo.

O discurso dominante hoje chama à aplicação de um direito internacional que autoriza em princípio a intervenção quando os direitos fundamentais de um povo estão desrespeitados. Mas as condições não estão reunidas para permitir avançar nesta direção. A comunidade internacional não existe. Resume-se ao embaixador dos Estados Unidos, seguido automaticamente pelos da Europa. Será preciso fazer a longa lista destas intervenções, mais que infelizes, criminosas nos seus resultados? (E o Iraque, por exemplo?) Será preciso recordar o princípio dois pesos, duas medidas que as caracteriza? (Pensar-se-á evidentemente nos direitos desrespeitados dos Palestinos e no apoio incondicional a Israel, bem como nas inúmeras ditaduras sempre apoiadas na África?)

\section{A PRIMAVERA DOS POVOS DO SUL E O OUTONO DO CAPITALISMO}

As "primaveras" dos povos árabes, como as que os povos da América Latina conhecem há duas décadas, que chamo a segunda

Temporalis, Brasilia (DF), ano 10, n.20, p.221-252, jul./dez. 2010. 


\section{temporalis}

AMIN, S. PRIMAVERA ÁRABE

onda do despertar dos povos do Sul - a primeira tinha se estendido no século $X X$ até a contraofensiva do capitalismo/imperialismo neoliberal -, tomam formas diversas que vão das explosões dirigidas contra as autocracias que acompanharam precisamente o estabelecimento neoliberal, até a recolocação em causa da ordem internacional pelos países emergentes. Tais primaveras coincidem, por conseguinte, com o Outono do capitalismo, o declínio do capitalismo dos monopólios generalizados, globalizados e financiarizados. Os movimentos começam como os do século precedente: com a reconquista da independência dos povos e dos Estados das periferias do sistema, retomando a iniciativa na transformação do mundo. Portanto, são, sobretudo, movimentos antiimperialistas e, por seu turno, apenas potencialmente anticapitalistas. Se esses movimentos chegam a convergir com o outro despertar necessário, o dos trabalhadores dos centros imperialistas, uma perspectiva autenticamente socialista poderia desenhar-se à escala da humanidade inteira. Mas isto não é, de forma alguma, inscrito de antemão como uma necessidade da história. O declínio do capitalismo pode abrir o caminho à longa transição ao socialismo como pode levar a humanidade sobre a via da barbárie generalizada. O projeto de controle militar do planeta pelas forças armadas dos Estados Unidos e dos seus aliados subalternos da OTAN, sempre em curso, o declínio da democracia nos países do centro imperialista e a recusa passadista da democracia nos países do Sul em revolta (que toma forma de ilusões parareligiosas fundamentalistas, que o Islã, o Hinduismo e o Budismo políticos propõem) operam juntos nesta perspectiva abominável. A luta para a democratização laica toma então uma dimensão decisiva no momento atual que opõe a perspectiva de uma emancipação dos povos à da barbárie generalizada.

Cairo e Paris, maio de 2011. 


\section{temporalis}

AMIN, S. PRIMAVERA ÁRABE

\section{LEITURAS COMPLEMENTARES}

AMIN, Samir. A life looking forward: memories of an independent marxist. Londres: Zed, 2006.

AMIN, Samir. La nation arabe. Paris: Minuit, 1976.

AMIN, Samir. L'éveil du Sud. Paris: Le temps des cerises, 2008.

RIAD, Hassan. L'Egypte nassérienne. Paris: Minuit, 1964.

O leitor encontrará nestes livros as minhas leituras das realizações do Vice-Rei Muhammad Ali (1805-1848) e dos Quedivas que lhe sucederam - em especial, Ismail (1867-79), o Wafd (1920-1952) -, das posições do comunismo egípcio perante o nasserismo, do desvio da Nahda de Afghani até Rachid Reda.

ACHCAR, Gilbert. Les Arabes et la Shoah. Arles: Actes Sud, 2009.

Trata-se da melhor análise dos componentes do Islã político (de Rachid Reda e da Irmandade Muçulmana, dos Salafistas modernos).

No que diz respeito à relação entre o conflito Norte/Sul e o que opõe o começo da transição socialista à continuação do desenvolvimento do capitalismo, ver:

ACHCAR, Gilbert. Le choc des barbaries. Bruxelas: Ed Complexe.

AMIN, Samir. La crise, sortir de la crise du capitalisme ou sortir du capitalisme en crise? Paris: Le Temps des Cerises, 2009.

AMIN, Samir. La loi de la valeur mondialisée. Paris: Le temps des cerises, 2011.

Temporalis, Brasilia (DF), ano 10, n.20, p.221-252, jul./dez. 2010. 
AMIN, Samir. Pour la cinquième internationale. Paris: Le temps des cerises, 2006.

AMIN, Samir. The long trajectory of historical capitalism. New York: Monthly Review, february 2011. 